\title{
STO LET OD OBJEVU ALZHEIMEROVY CHOROBY
}

\author{
Bohumír Plucar ${ }^{1}$, Jiř́i Patočka ${ }^{2}$
}

IX: 1 - 211, 2007

ISSN 1212-4117

${ }^{1}$ Univerzita Karlova v Praze, 1. lékařská fakulta , Ústav pro humanitní studia v lékařství

2Jihočeská univerzita v Českých Budějovicích, Zdravotně sociální fakulta, katedra radiologie a toxikologie

\begin{abstract}
Alzheimerova choroba, progresivní neurodegenerativní onemocnění charakteristické specifickým souhrnem patofyziologických změn v mozku, se stala pandemií 21. století. Nemoc dosud neznámé etiologie ve svých důsledcích vede $k$ těžké neschopnosti a smrti. Začíná nenápadně, ale postupně vede ke ztrátě kognitivních funkcí a rozpadu osobnosti a bývá nejčastější pŕícinou demence. Ta pak nutně vede $\mathrm{k}$ závislosti nemocného na každodenní pomoci jiného člověka. V průběhu choroby nemocný postupně ztrácí prostorovou a časovou orientaci, neuvědomuje si, kde je, jaké je datum, kolik je mu let, nepoznává ani své nejbližší a nakonec ztrácí i povědomí o tom, kdo je, čím byl, zda má děti apod. (Koukolík, Jirák, 1998). Alzheimerova choroba je chorobou stáŕí, a tak s prodlužující se délkou života stoupá její incidence. Ve skupině 65letých jsou postiženy zhruba 2 až $3 \%$ populace a každých dalších 5 let se toto procento zdvojnásobuje. Ve skupině 80letých je již postižena polovina populace. Existují ale i vzácnější formy demencí s časným začátkem vzniku, např. již kolem 40. až 50. roku. V současné době se odhaduje, že je ve světě kolem 20 milionů lidí, trpících touto chorobou. V České republice se počet postižených odhaduje na cca 80000 .
\end{abstract}

Již 100 let uplynulo od prvních klinických a histologických popisů této nemoci německým lékařem Aloisem Alzheimerem a 21. zář́i 2006 se slavilo toto výročí Světovým Alzheimerovým dnem. Tento retrospektivní přehled důležitých událostí a milníků ve výzkumu Alzheimerovy choroby představuje její ranou historii, ve které byly popisovány pouze klinické a histologické prríznaky této zvláštní choroby. Elektronová mikroskopie, kvantitativní morfologie a moderní biochemie, objevující se ve druhé polovině 20. století, otevřela novou éru ve výzkumu demence, když pomohla popsat ultrastrukturu a biochemii senilních plaků a neuronálních uzlíčků, tzv. tangles, hlavních markerů Alzheime- rovy choroby. Následoval pokrok ve vývoji klinických, neuropatologicko-zobrazujících metod. Moderní nástroje a algoritmy v diagnóze tohoto onemocnění umožnily dlouhodobé studie a přesnější stanovení diagnózy Alzheimerovy choroby a príbuzných chorob. Zásadními studiemi Alzheimerovy choroby byly ty, které určily stadia a kritéria pro určení diagnózy post mortem, založené na semikvantitativním hodnocení jejích hlavních markerů, včetně nervových růstových faktorů. Základní výzkum umožnil nahlédnout do molekulární genetiky a patofyziologie Alzheimerovy choroby a na základě biochemických nálezů byly otevřeny nové možnosti farmakologické léčby. Nejnovějším objevem je nález zmutovaného genu SORL1 u pacientů s Alzheimerovou nemocí (Rogaeva et al., 2007). Nejnovější biologické a jiné metody studia metabolismu mozku, zvláště neinvazivní zobrazující metody jako je MRI nebo SPECT, umožňují časnou detekci markerů již v presymptomatických stadiích Alzheimerovy choroby (Matsuda, 2006). Progresi rizikových faktorů a tím onemocnění může být $\mathrm{v}$ budoucnosti preventivně zabráněno nebo alespoň může být zpomaleno pomocí nových terapeutických postupů, kombinujících vhodným způsobem a načasováním farmakologickou a nefarmakologickou intervenci.

Protože etiologie Alzheimerovy choroby je doposud neznámá, kauzální způsoby léčby nejsou zatím dostupné. Současná terapie je pouze symptomatická a jejím hlavním cílem je oddálit deterioraci kognitivních funkcí a snížit rychlost jejího postupu, léčit poruchy chování, deprese, anxietu, poruchy spánku, halucinace, paranoidní syndromy a řešit somatické potíže, které demenci provázejí. Patří sem zejména inkontinence, poruchy polykání, nespecifické bolesti, komorbidity a interkurentní onemocnění. Komplexní léčba zahrnuje i psychosocioterapii (behaviorální trénink), rehabilitaci a práci 
s rodinou. Hlavním praktickým úkolem je umožnit setrvání pacienta $\mathrm{v}$ domácí péči v kruhu rodiny a zachovat jeho schopnost postarat se sám o sebe. Úkolem terapie je zejména zlepšit kvalitu provádění běžných denních aktivit a snížit nebo alespoň nezvyšovat zátěž a stres pečovatelů. Důležitou a zatím jedinou obecně přijímanou prevencí demence je udržování stálé duševní aktivity, která může zvýšit rezervy mozku (Rektorová, 2002). Takový př́istup ovšem zvyšuje nároky na ošetřovatelskou péči v rodině či zařízeních sociální péče a na kvalifikaci ošetřujícího personálu. Práce sociálních pracovníků s rodinou je významnou složkou ošetřovatelské péče o pacienta s Alzheimerovou nemocí a musí být založena na oboustranné ochotě ke spolupráci.

Farmakologická intervence je zaměřena na zlepšení kognitivních funkcí mozku zvýšením hladiny mozkového acetylcholinu, kterého lze dosáhnout podáváním centrálně účinných reverzibilních inhibitorů cholinesterázy, jako je rivastigmin, donepezil či galantamin (Birks, 2006). Nadějným léčivem je také memantin, nízkoafinitní antagonista NMDA receptorů (Patočka, 2002). Tato léčiva však nedokáží chorobu vyléčit, pouze zpomalí její postup. Proto všechny vědecké články konstatují nutnost dalšího vý- zkumu a vyzývají k vývoji nových diagnostických strategií pro časnou a přesnou detekci neurodegenerativních procesů, vedoucích $\mathrm{k}$ demenci, a k vývoji nových typů léčiv (viz např. Patočka, Strunecká, 2006; Patočka, 2006). Lepší využití epidemiologických a rodových dat stejně jako hlubší pohled do patogenetické kaskády Alzheimerovy choroby a dalších druhů demence, to vše závisí na mezinárodní síti úzké spolupráce mezi kliniky, neurovědci, zdravotními institucemi a individuálními sponzory.

\section{LITERATURA}

BIRKS, J.: Cholinesterase inhibitors for Alzheimer's disease. Cochrane Database Syst Rev. 2006 Jan 25; (1):CD005593.

KOUKOLÍK, F., JIRÁK, R.: Alzheimerova nemoc a další demence. Praha: Grada Publishing 1998. s. 232.

MATSUDA, H.: Functional neuroimaging in Alzheimer's disease. Radiat Med. 2006. Vol.24, s. 302-308.

PATOČKA, J.: Memantin a jeho terapeutický potenciál u degenerativních poruch CNS. Psychiatrie 2002. Vol. 6, s. 35-40.

PATOČKA, J., STRUNECKÁ, A.: Xaliproden a jeho neuroprotektivní potenciál. Psychiatrie 2006. Vol. 10, s. 157-159.

REKTOROVÁ, I.: Terapie demencí. Neurologie pro praxi 2002. Vol. 4, s. 260-263.

ROGAEVA, E. et al.: The neuronal sortilin-related receptor SORL1 is genetically associated with Alzheimer disease. Nat. Genet 2007 Jan 14, DOI: 10.1038/ng1943.

Jiř́ Patočka a Bohumír Plucar prof.patocka@gmail.com 